\title{
Development of Video Tutorials on Making Paper-Based Literature Review to Improve Student Literacy Ability in the Coronavirus Disease (COVID-19) Pandemic
}

\author{
Warju $^{1 *}$, Nadi Suprapto ${ }^{2}$, Neni Mariana ${ }^{3}$, Sukma Perdana Prasetya ${ }^{4}$, Mochammad Arif Al \\ Ardha $^{5}$, Sudirman Rizki Ariyanto ${ }^{6}$ \\ ${ }^{1}$ Department of Mechanical Engineering Faculty of Engineering, Universitas Negeri Surabaya, Surabaya, Indonesia \\ ${ }^{2}$ Department of Primary School Teacher Education Faculty of Education, Universitas Negeri Surabaya, Surabaya, Indonesia \\ ${ }^{3}$ Department of Primary School Teacher Education Faculty of Education, Universitas Negeri Surabaya, Surabaya, Indonesia \\ ${ }^{4}$ Department of Geography Education Faculty of Social Sciences and Law, Universitas Negeri Surabaya, Surabaya, Indonesia \\ ${ }^{5}$ Department of Sports Education Faculty of Sport Sciences, Universitas Negeri Surabaya, Surabaya, Indonesia \\ ${ }^{6}$ Automotive Technology Vocational Education Faculty of Science and Technology, Universitas Bhinneka PGRI Tulungagung \\ Tulungagung, Indonesia \\ *Corresponding Author. Email : warju@unesa.ac.id
}

\begin{abstract}
The COVID-19 pandemic has spread in various countries. Especially in the education sector, COVID-19 has an impact on the implementation of learning that has changed from face-to-face to online. Besides, due to conditions that do not allow data collection in the field/laboratory, currently, many supervisors tend to direct their students to conduct literature studies. This research and development use Peter Fenrich's instructional development model to develop a video tutorial for making scientific articles based on literature reviews. This model, consisting of six development phases, includes the analysis, planning, design, development, implementation, and evaluation and revision phases. Data collection techniques are carried out by providing validation sheets to validators to assess video tutorials based on aspects of language, content, and design using google forms. Also, a questionnaire was used to determine student responses after seeing the video tutorial using Google Forms. Data analysis using quantitative descriptive techniques. Based on data analysis, it is known that the instruments developed are valid, reliable, and practical so that they are suitable for use as a reference for students in compiling scientific articles based on literature reviews. This is evidenced by (1) the validation results of 3.55 with valid criteria; (2) the reliability test results are 0.413 with the criteria are quite reliable; and (3) practicality test results of 3.40 with practical criteria.
\end{abstract}

Keywords: video tutorials, literature review, instructional development cycle, COVID-19

\section{INTRODUCTION}

The Corona Virus Disease (COVID-19) pandemic has spread in various countries in Asia, Africa, North America, South America, Europe, and Australia. To date, it has been recorded that there have been $25,547,169$ cases of COVID19 , of which 852,987 people have been declared dead, and $17,825,719$ people have been declared recovered [1]. The cases that have arisen due to COVID-19 have certainly had serious impacts in various sectors of life, including the education sector. Several efforts were made by the minister of education to suppress the emergence of new COVID-19 clusters in the education sector. One of the major efforts made is by issuing a Circular of the Minister of Education and Culture Number: 36962/MPK.A/HK/2020 [2].

Through this circular, the ministry of education issued a policy that specifically for areas that have been affected by COVID-19, they must carry out online learning [3]. his policy is certainly not encouraging news for all practitioners of the world of education, but both teachers and lecturers must adapt immediately. This of course, makes teachers and lecturers have to be able to provide thorough preparation so that they are still able to deliver quality learning even during the COVID-19 pandemic.

As one of the state higher education institutions in Indonesia, Universitas Negeri Surabaya (Unesa) esponds 
quickly to policies that have been given by the government. One of them is by publishing the Unesa Chancellor's Circular Number: B/152/UN38/TU.00.02/2020 concerning measures to prevent the spread of COVID-19 in Unesa's environment [4]. Referring to this circular, the Chancellor of Unesa gave a policy that theoretical lectures were carried out online, and practicum lectures were carried out by providing relevant assignments as a solution to meeting learning achievement targets.

Not only that, but the effect of the policies issued by the Unesa Chancellor also had an impact on the process of running academic guidance, guidance for report preparation, and the implementation of industrial practice exams/job training/final projects/theses/theses/dissertations, all of which were carried out online. Especially for the implementation of online thesis guidance as one of the requirements in taking an undergraduate program, of course, still leaves problems. Among them are limited time, effort, cost, effectiveness, and efficiency of the guidance implementation process. Responding to this problem, the Chancellor of Unesa issued a Circular of the Unesa Chancellor Number: B/17447/UN/38/HK.01.01/2020 concerning the replacement of theses into scientific articles for Unesa students who program Thesis courses in the even semester 2019/2020 [5].

However, the replacement of a thesis into a scientific article still leaves several problems, one of which is the difficulty of collecting primary research data during the COVID-19 pandemic. Therefore, some supervisors direct their students to conduct literature studies. Literature study research, or it can also be called a systematic literature review, is generally carried out to identify, select, and critically assess the research to answer formulated questions [6]. Meanwhile, Maggio et al. (2016) define a literature study as a synthetic review and a summary of what is known and what is not known about a problem that cannot be investigated directly by researchers [7].

Literature studies have been carried out in several studies. Arifin et al. (2020) conducted a literature study to evaluate the concept of Technology, Pedagogy, and Content Knowledge (TPACK), which is used as a concept of vocational education. The research results recommend that the TPACK concept can be transformed into the concept of Technology, Andragogy, Work, and Content Knowledge (TAWOCK) in vocational learning. However, the conceptual model of the TAWOCK framework for vocational fields needs to be tested [8].

Ariyanto et al. (2019) conducted a literature study research to develop a Collaborative Problem-Based Learning (CPBL) model. The results showed that the CPBL is the right model when applied in vocational high schools.
This model is considered and appropriate because it can develop students' ability to solve problems. Besides, this model is also predicted to be able to develop students abilities to be skilled in working both individually and in teams [9].

Warju et al. (2018) conducted a literature study research to analyze the automotive engineering study program curriculum that is integrated with environmental education in vocational high schools. The results show that conceptually, the automotive engineering study program curriculum integrated with EE in SMK is an ideal model if a green school program applies it (after this, 'Adiwiyata'). This model has a solid foundation because it is developed through several stages that must be carried out sequentially, starting from the first to the last stage [10].

Warju (2016) conducted a literature study to analyze evaluation models that can be used to evaluate a program. The result is that the most widely used model is the CIPP model. This model consists of evaluating context, input, process, and product [11]. Context evaluation is used to determine the extent to which program goals and objectives have been achieved [12]. Input evaluation is used to assist in making decisions about how facilities, human resources, and budgets will be determined and shaped to achieve educational goals [13]. Process evaluation for ongoing examination of program implementation plans and process notes [14]. Product evaluation measures and analyzes outcomes during and after education and checks overall program efficacy [15].

From relevant research, it is proven that literature studies are ideal if used to conduct research using secondary data. However, at the undergraduate level, literature studies research is still not widely used. Referring to this, this research was conducted to develop a video tutorial video on making scientific articles based on literature reviews to improve student literacy skills during the COVID-19 pandemic.

\section{METHOD}

This research and development use Peter Fenrich's instructional development model. This development model has six development phases, including the analysis, planning, design, development, implementation, and evaluation and revision phases [16]. The test subjects in this study were nine expert validators and 11 Unesa students who programmed the Thesis course in the even semester of 2019/2020, totaling 11 students. The nine validators consist of three design expert validators, three material expert validators, and three linguist validators.

Data collection techniques are carried out by providing validation sheets to validators to assess video tutorials based 
on aspects of language, content, and design using google forms. Besides, a questionnaire was used to determine student responses after seeing the video tutorial using Google Forms. The data obtained in this study, namely: instrument validation data from experts and reliability data, and practical video tutorial data. The data obtained were then analyzed to determine the level of validity, reliability, and practicality of the developed video tutorials. Data analysis used quantitative descriptive techniques using SPSS 24 software.

\section{RESULT AND DISCUSSION}

\subsection{RESULT}

The results in this study are the implementation of each stage of the Peter Fenrich model, as shown in Figure 1.

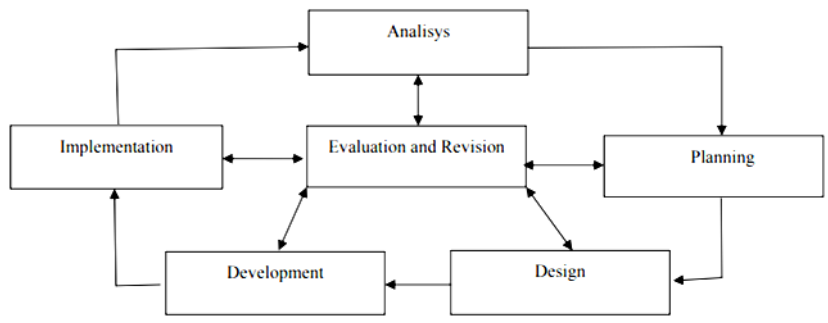

Fig. 1. Peter Fenrich's model of instructional development cycle

\section{1) Analysis Phase}

The instructional development cycle begins with an analysis phase. Activities at the initial stage are defining essential problems that need to be resolved immediately and determining whether these problems require multimedia instructional development solutions. From the results of the analysis, it was found that during the COVID-19 pandemic, social and physical distancing had to be done so that the need to learn from home with online learning became a necessity [17]. During this COVID-19 pandemic, students desperately need multimedia-based media for their learning facilities, especially in terms of making scientific articles due to limited time to meet with supervisors [18]. Therefore, the development of video tutorials for making scientific articles based on literature reviews for Unesa students who are programming Thesis courses during the COVID-19 pandemic must be done immediately.

\section{2) Planning Phase}

Working at the planning stage is very helpful to ensure that the progress of work is progressing well and as expected. The main components of the planning phase include identification and statement of significant problems. Researchers, as video tutorial developers anticipate how to minimize the impact of the risk of transmitting COVID-19, but learning will continue to its full potential. In this phase, ideal designs and concepts are formulated in making video tutorials so that students can easily understand making scientific articles based on literature reviews [19].

\section{3) Design Phase}

Based on the essential problems that exist, namely the COVID-19 pandemic and the learning outcomes of the Thesis course, which requires them to write scientific articles, the next step is the design phase to create a learning strategy. This phase determines what strategies need to be done to ensure that students will learn effectively and efficiently [20]. On the other hand, in the design phase, standards and tutorial videos were also set. Furthermore, the instrument grid is also formulated, which will be used by the validator in conducting validation [21]. Details of the aspects used in the assessment can be seen in the following table.

TABLE I. DETAIL OF ASSESSMENT ASPECT OF VALIDATION INSTRUMENTS

\begin{tabular}{ccc}
\hline No & \multicolumn{1}{c}{ Aspects Assessed } & Number of Items \\
\hline 1. & Aspects of Presentation & 14 \\
2. & Aspects of Material Quality & 8 \\
3. & Aspects of Language & 5 \\
\hline & Total Item Ratings & $\mathbf{2 7}$ \\
\hline
\end{tabular}

\section{4) Development Phase}

The development phase is the core activity of $R \& D$ research. In this phase, it is to make a planned video tutorial based on the selected learning strategy, the selected media, the chosen design specifications and is a fundamental element of development and programming (multimedia) activities [22]. Activities in the development phase include: (1) making video tutorials for making scientific articles based on literature reviews for the implementation of learning strategies and design specifications that have been made in the design phase, (2) based on student needs, video tutorials are needed to teach students to make scientificbased articles. Literature review, (3) developing and selecting video tutorial material, and (4) evaluating and making revisions.

The next stage of development is to test the validity of the tutorial video to expert validators. The validity test was also conducted to test the feasibility of the video tutorials being developed. More specifically, the results of the expert validity test can be seen in Table 2 .

TABLE II. VIDEO TUTORIAL VALIDATION RESUlTS

\begin{tabular}{|c|c|c|c|}
\hline No & Aspects Assessed & Average & Criteria \\
\hline 1. & Aspects of Presentation & 3.38 & Quite Valid \\
\hline 2. & Aspects of Material Quality & 3.67 & Valid \\
\hline 3. & Aspects of Language & 3.60 & Valid \\
\hline & Total Average & 3.55 & Valid \\
\hline
\end{tabular}

5) Implementation Phase 
In the implementation phase, the video tutorials for making scientific articles based on literature reviews were tested using the Mendeley application into real learning situations to find out whether the video tutorials were effective and efficient in learning and what needs to be revised. The implementation was carried out on 11 Unesa students who were programming Thesis courses. Evaluation is an integral component of implementation [23], [24]. This stage is carried out to test the reliability of the tutorial video. Reliability was tested using Cronbach's Alpha technique assisted by SPSS 24 software. The results are shown in Table 3.

TABLE III. CRONBACH'S ALPHA TEST RESUlTS

\begin{tabular}{cc}
\hline \multicolumn{2}{c}{ Reliability Statistics } \\
\hline Cronbach's Alpha & N of Items \\
\hline 0.413 & 11 \\
\hline
\end{tabular}

After being tested for reliability, the video tutorial developed was also tested for its practicality. The goal is to serve as a reference and evaluation material from the use of video tutorials for making scientific articles based on literature reviews. More specifically, the results of the practicality test can be seen in Table 4.

TABle IV. VIDEO TUtorial PRACTICAL Test Results

\begin{tabular}{|c|c|c|c|c|c|c|c|c|c|c|c|c|c|c|}
\hline \multirow{2}{*}{$\begin{array}{l}\text { No. } \\
\text { Item }\end{array}$} & \multicolumn{11}{|c|}{ Respondents } & \multirow{2}{*}{$\begin{array}{c}\text { Item } \\
\text { Average }\end{array}$} & \multirow{2}{*}{$\begin{array}{c}\text { Total } \\
\text { Average }\end{array}$} & \multirow{2}{*}{ Criteria } \\
\hline & $\mathbf{R 1}$ & $\mathbf{R 2}$ & R3 & R4 & R5 & R6 & R7 & $\mathbf{R 8}$ & R9 & R10 & R11 & & & \\
\hline 1 & 3 & 3 & 4 & 3 & 4 & 3 & 2 & 4 & 2 & 4 & 3 & 3.18 & \multirow{16}{*}{3.40} & \multirow{16}{*}{ Practically } \\
\hline 2 & 4 & 3 & 4 & 3 & 4 & 3 & 3 & 4 & 3 & 3 & 2 & 3.27 & & \\
\hline 3 & 3 & 3 & 4 & 3 & 4 & 3 & 3 & 3 & 3 & 4 & 3 & 3.27 & & \\
\hline 4 & 4 & 3 & 4 & 3 & 4 & 3 & 3 & 4 & 3 & 4 & 4 & 3.55 & & \\
\hline 5 & 3 & 3 & 4 & 4 & 4 & 3 & 4 & 4 & 3 & 4 & 3 & 3.55 & & \\
\hline 6 & 3 & 4 & 4 & 3 & 4 & 3 & 3 & 4 & 3 & 3 & 3 & 3.36 & & \\
\hline 7 & 3 & 3 & 4 & 3 & 4 & 3 & 3 & 4 & 3 & 4 & 4 & 3.45 & & \\
\hline 8 & 3 & 4 & 4 & 4 & 4 & 3 & 3 & 3 & 3 & 4 & 2 & 3.36 & & \\
\hline 9 & 4 & 3 & 4 & 3 & 4 & 3 & 3 & 3 & 3 & 4 & 3 & 3.36 & & \\
\hline 10 & 3 & 3 & 4 & 4 & 4 & 3 & 3 & 4 & 3 & 4 & 4 & 3.55 & & \\
\hline 11 & 3 & 3 & 4 & 3 & 4 & 3 & 3 & 3 & 3 & 4 & 4 & 3.36 & & \\
\hline 12 & 3 & 3 & 4 & 3 & 4 & 3 & 3 & 4 & 3 & 4 & 3 & 3.36 & & \\
\hline 13 & 3 & 4 & 4 & 3 & 3 & 3 & 3 & 4 & 3 & 4 & 4 & 3.45 & & \\
\hline 14 & 3 & 3 & 4 & 3 & 4 & 3 & 3 & 4 & 3 & 4 & 4 & 3.45 & & \\
\hline 15 & 3 & 3 & 4 & 3 & 4 & 3 & 3 & 3 & 3 & 4 & 3 & 3.27 & & \\
\hline 16 & 4 & 3 & 4 & 4 & 4 & 3 & 3 & 3 & 3 & 4 & 4 & 3.55 & & \\
\hline
\end{tabular}

\section{6) Evaluation Phase}

The evaluation phase includes systematic collection and analysis of information for decision making and planning. Evaluation is a process that must continue in the instructional development cycle [25]. Besides, evaluation is also carried out to analyze whether the video tutorials developed have been able to support students in making scientific articles based on literature reviews as desired by both lecturers and students.

\section{7) Fase Revisi}

The revision phase is based on feedback and data collected during the evaluation phase. The revision phase also continues throughout the instructional development cycle [26]. Therefore, evaluations and revisions will continue to be carried out to produce video tutorials for making scientific articles based on literature reviews using the Mendeley application that is effective and efficient in learning. 


\subsection{DISCUSSION}

\section{8) Validity of the Video Tutorial}

A good learning video must be valid and reliable so that it is suitable for use in the learning process [27]. Dong \& Goh (2015) menjelaskan bahwa video yang layak dapat memberikan stimulis yang positif pada siswa meskipun pembelajaran dilakukan secara online ataupun mandir Dong \& Goh (2015) explain that a good video can provide positive stimulation to students, even though learning is done online or independently [28]. On the other hand, Behehsti et al. (2018) showed that activities supported by instructional videos enable active learning [29]. Although several studies also mentioned that video could be used as a useful tool in education [30].

According to Table 2, we can see that the validity test of the instructional videos is divided into three aspects of assessment, such as aspects of presentation, quality of material, and language. The presentation aspect gets an average value of 3.38 with quite valid criteria. The quality aspect of the material gets an average value of 3.67 with valid criteria. Meanwhile, the language quality aspect receives an average score of 3.60 with valid criteria. These results indicate that from the three aspects of the assessment, it is stated that the video tutorials for making scientific articles based on literature reviews that were developed are following the needs of Unesa students who are programming the Thesis course.

\section{9) Reliability of the Video Tutorial}

Reliability was tested to analyze the ability of the video tutorial when it was replicated. Livingston (2018) states that reliability testing is essential because it can be used as a measure of the reliability of the instructional videos developed [31]. The video tutorial reliability test was conducted based on student responses directly after seeing the developed video tutorials. In this case, the research respondents were 11 Unesa students who program Thesis courses in the even semester 2019/2020.

The results of the tutorial video reliability test are shown in Table 3, where it is known that the Cronbach's value obtained was 0.413 from 11 respondents. This value is adjusted to the criteria of "reliable enough" level of reliability. Referring to this, it can be stated that the video tutorial for making scientific articles based on the literature review developed is feasible to be used to improve student literacy skills during the COVID-19 pandemic.

\section{0) Practical Video Tutorials}

Practicality is an essential condition that cannot be ignored in developing video tutorials. In several ways, Ariyanto, Munoto, \& Muhaji, (2019) explained that practicality is related to the ease with which a medium is used in the learning process [32]. he practicality test in this study can be measured after students respond to the learning videos that have been developed. Through the test results, the average value of the 11 respondents was 3.40 , with practical criteria.

Referring to these results, Djamas et al. (2018) explained that practicality testing generally involves three aspects of assessment, such as learning ability, effectiveness, and satisfaction [33]. Thus, it can be stated that the video tutorials developed are very practical and easily understood by students who are writing literature review-based scientific articles.

\section{CONCLUSION}

The results of the assessment provided by expert validators show that the video tutorials for making scientific articles based on literature reviews are following the needs of Unesa students who program their thesis courses. This is evidenced by the average value of all aspects of the assessment (aspects of presentation, material quality, and language), which fall into the valid criteria with the validation result of 3.55. Also, through student responses, information was also obtained that the video tutorials developed were able to improve student understanding of writing literary review-based scientific articles to improve student literacy skills during the COVID-19 pandemic. This statement is evidenced by the acquisition of a reliability value of 0.413 with the criteria is quite reliable. Then, in terms of practicality, the video tutorial developed was stated to be practical. This is evidenced by the acquisition of an average practicality test value of 3.40 from eleven respondents.

\section{REFERENCES}

[1] Worldometer, "Coronavirus Updates," 2020. https://www.worldometers.info/.

[2] Minister of Education and Culture, Circular Number: 36962 /MPK.A/HK/2020 concerning Online Learning and Working from Home in Order to Prevent Corona Virus Disease (COVID-19). Indonesia: Minister of Education and Culture, 2020.

[3] A. Abidah, H. N. Hidaayatullaah, R. M. Simamora, D. Fehabutar, and L. Mutakinati, "The Impact of Covid-19 to Indonesian Education and Its Relation to the Philosophy of 'Merdeka Belajar,"' Stud. Philos. Sci. Educ., vol. 1, no. 1, pp. 38-49, Apr. 2020, doi: 10.46627/sipose.v1i1.9.

[4] Rector Unesa, Rector Unesa Circular No: B/152/UN38/TU.00.02/2020 concerning measures to prevent the spread of Covid-19 in the Unesa environment. Indonesia: Universitas Negeri Surabaya, 2020.

[5] Rector Unesa, Rector Unesa Circular No: 
B/17447/UN/38/HK.01.01/2020 Year 2020 concerning the replacement of theses into scientific articles for Unesa students. Indonesia: Universitas Negeri Surabaya, 2020.

[6] A. Dewey and A. Drahota, "Module 1: Introduction to conducting systematic reviews | Cochrane Training," 2016. https://training.cochrane.org/interactivelearning/mo dule-1-introduction-conducting-systematic-reviews (accessed Sep. 02, 2020).

[7] L. A. Maggio, J. L. Sewell, and A. R. Artino, "The Literature Review: A Foundation for High-Quality Medical Education Research.," J. Grad. Med. Educ., vol. 8, no. 3, pp. 297-303, Jul. 2016, doi: 10.4300/JGME-D-16-00175.1.

[8] Z. Arifin, M. Nurtanto, W. Warju, R. Rabiman, and N. Kholifah, "The TAWOCK conceptual model at content knowledge for professional teaching in vocational education," Int. J. Eval. Res. Educ., vol. 9, no. 3, pp. 697-703, 2020, doi: 10.11591/ijere.v9i3.20561.

[9] S. R. Ariyanto, Munoto, S. Muslim, and Muhaji, "Collaborative Problem-Based Learning Models Implementation in Vocational High Schools," 2019, doi: 10.2991/assehr.k.191217.039.

[10] Warju, S. R. Ariyanto, and L. Muzaki, "Developing integrated curriculum with environmental education at vocational high school," in International Conference on Indonesian Technical Vocational Education and Association (APTEKINDO 2018), 2018, vol. 201, pp. 21-27.

[11] Warju, "Educational Program Evaluation using CIPP Model," Innov. Vocat. Technol. Educ., vol. 1, pp. 3642, 2016.

[12] K. A. Umam and I. Saripah, "Using the Context, Input, Process and Product (CIPP) Model in the Evaluation of Training Programs," Int. J. Pedagog. Teach. Educ., vol. 2, p. 19, Dec. 2018, doi: 10.20961/ijpte.v2i0.26086.

[13] Y.-J. Kim and E.-G. Son, "A Study on Satisfaction of New Nurse Orientation Program Applying CIPP Evaluation Model Focusing on Affiliated Hospitals of an Educational Foundation in South Korea.," J. Korea Acad. Coop. Soc., vol. 18, no. 9, pp. 226-235, 2017.

[14] S. Y. Lee, J.-S. Shin, and S.-H. Lee, "How to execute Context, Input, Process, and Product evaluation model in medical health education.," J. Educ. Eval. Health Prof., vol. 16, p. 40, 2019, doi: 10.3352/jeehp.2019.16.40.

[15] S. young Lee, J.-S. Shin, and S.-H. Lee, "How to execute Context, Input, Process, and Product evaluation model in medical health education," $J$. Educ. Eval. Health Prof., vol. 16, p. 40, Dec. 2019, doi: 10.3352/jeehp.2019.16.40.

[16] P. Fenrich, Practical Guidelines for Creating Instructional Multimedia Applications, 1 st ed. Harcourt College Pub, 1997.

[17] W. Ali, "Online and Remote Learning in Higher Education Institutes: A Necessity in light of COVID19 Pandemic," High. Educ. Stud., vol. 10, no. 3, p. 16, May 2020, doi: 10.5539/hes.v10n3p16.

[18] R. H. Huang, D. J. Liu, A. Tlili, J. F. Yang, and H. $\mathrm{H}$. Wang, Handbook on facilitating flexible learning during educational disruption: The Chinese experience in maintaining undisrupted learning in COVID-19 Outbreak. Beijing: Smart Learning Institute of Beijing Normal University, 2020.

[19] W. Faridah and W. Warju, "Pengembangan Modul Pembelajaran Injector Tester Dan Ultrasonic Cleaner CNC-6011 Pada Mata Kuliah Praktik Motor Bensin Program Studi S-1 Pendidikan Teknik Mesin," J. Pendidik. Tek. Mesin, vol. 2, no. 03, pp. 58-66, 2014.

[20] P. Fenrich, "Instructional Design Tips for Virtually Teaching Practical Skills," Proc. 2004 InSITE Conf., 2004, doi: 10.28945/2752.

[21] S. R. Ariyanto, M. Munoto, and M. Muhaji, "Development of affective authentic assessment instruments for automotive engineering expertise in vocational school," J. Taman Vokasi, vol. 7, no. 1, p. 42, Jul. 2019, doi: 10.30738/jtv.v7i1.4777.

[22] P. J. Fenrich, "Evaluation Of Educational-Software and Paper-Based Resources for Teaching LogicalThinking Skills to Grade Six and Seven Students," Open University Malaysia, 2015

[23] D. Guyadeen and M. Seasons, "Evaluation Theory and Practice: Comparing Program Evaluation and Evaluation in Planning," J. Plan. Educ. Res., vol. 38, no. 1, pp. 98-110, Mar. 2018, doi: $10.1177 / 0739456 X 16675930$.

[24] A. W. Frye and P. A. Hemmer, "Program evaluation models and related theories: AMEE Guide No. 67," Med. Teach., vol. 34, no. 5, pp. e288-e299, May 2012, doi: 10.3109/0142159X.2012.668637.

[25] M. K. Khalil and I. A. Elkhider, "Applying learning theories and instructional design models for effective instruction," Adv. Physiol. Educ., vol. 40, no. 2, pp. 147-156, Jun. 2016, doi: 10.1152/advan.00138.2015.

[26] S. TRI UMAROH and Warju, "Pengembangan Modul Smoke Opacity Meter Tecnomotor Tipe G820 Untuk Menunjang Mata Kuliah Analisa Performa Mesin Pada Mahasiswa S1 Pendidikan Teknik Mesin FT Unesa," J. Pendidik. Tek. Mesin, 
vol. 8, no. 2, pp. 111-122, 2019.

[27] G. H. Selaras, Y. Ahda, and H. Alberida, "The Validity and Reliability of The Instrument Assessment of Higher Order Thinking Skill on The Biological Scope Materials," Bioeducation J., vol. 3, no. 2, pp. 124-125, 2019.

[28] C. Dong and P. S. Goh, "Twelve tips for the effective use of videos in medical education," Med. Teach., vol. 37, no. 2, pp. 140-145, Feb. 2015, doi: 10.3109/0142159X.2014.943709.

[29] M. Behehsti, A. Taspolat, O. S. Kaya, and H. F. Sapanca, "Characteristics of instructional videos," World J. Educ. Technol. Curr. Issues, vol. 10, no. 2, pp. 79-87, May 2018, doi: 10.18844/wjet.v10i2.3418.

[30] Warju, S. R. Ariyanto, Soeryanto, R. S. Hidayatullah, and M. Nurtanto, "Practical Learning Innovation: Real Condition Video-Based Direct Instruction Model in Vocational Education," J. Educ. Sci. Technol., vol. 6, no. 1, pp. 79-91, 2020.

[31] S. A. Livingston, "Test Reliability - Basic Concepts," 2018.

[32] S. R. Ariyanto, M. Munoto, and M. Muhaji, "Development of Psychomotor Domain Assessment Instrument on Brake System Competence in SMKN 1 Jetis Mojokerto," Int. J. Educ. Vocat. Stud., vol. 1, no. 6, Aug. 2019, doi: 10.29103/ijevs.v1i6.1648.

[33] D. Djamas, V. Tinedi, and Yohandri, "Development of Interactive Multimedia Learning Materials for Improving Critical Thinking Skills," Int. J. Inf. Commun. Technol. Educ., vol. 14, no. 4, pp. 66-84, Oct. 2018, doi: 10.4018/IJICTE.2018100105. 